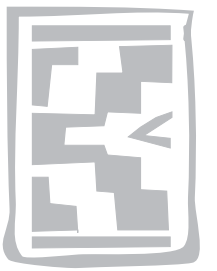

\title{
Effect of urea-molasses block supplementation on grazing weaner goats naturally infected with gastrointestinal nematodes
}

\author{
R.M. WARUIRU*, J.W. NGOTHO and M.N. MUTUNE \\ Department of Veterinary Pathology, Microbiology and Parasitology, Faculty of Veterinary Medicine \\ University of Nairobi, P.O. Box 29053-00625, Kangemi-Nairobi, Kenya
}

\begin{abstract}
WARUIRU, R.M., NGOTHO, J.W. \& MUTUNE, M.N. 2004. Effect of urea-molasses block supplementation on grazing weaner goats naturally infected with gastrointestinal nematodes. Onderstepoort Journal of Veterinary Research, 71:285-289

The influence of feeding urea-molasses blocks (UMB) on growth and gastrointestinal (GI) nematode parasitism of weaner goats grazing the same pasture was investigated on a farm in Nyandarua District, Kenya. Thirty female Small East African goat kids at an average age of 5 months were initially treated with albendazole orally $\left(5 \mathrm{mg} \mathrm{kg}^{-1}\right.$ body mass) and randomly assigned into one of two groups: group I were fed UMB prepared using a cold process and group II kids (controls) received no block supplementation (NBS). The UMB were given in the evening when the animals returned from grazing and were consumed during the night at a rate of $95.0 \mathrm{~g} \mathrm{head}^{-1}$ day $^{-1}$. Supplementation was undertaken for 3 consecutive months from July to September 2001 and January to March 2002. Body mass of the kids and faecal egg counts were measured monthly and larval cultures were performed on positive faecal samples of kids of each group. Five goats from each group were randomly selected for slaughter and total counts and identification of worms at the end of June 2002. Significant differences $(P<0.05)$ were found in cumulative mass gains of kids in group I from September compared with those in group II. On termination of the study kids in group I had gained an average of $( \pm S D) 20.4 \pm 1.4 \mathrm{~kg}$ while those in group II had gained $11.8 \pm 1.1 \mathrm{~kg}$. From January 2002, faecal egg counts of the kids in the UMB group differed significantly $(P<0.05)$ from those of the NBS group and at slaughter, the mean $( \pm$ SD) worm counts for the UMB group was $482 \pm 299$ while that of the NBS group was $1302 \pm 410$. In all the goats, Haemonchus contortus was the predominant nematode recovered. These results indicate that UMB had significant effects in the control of GI nematode parasitism and enhanced growth of the young goats.
\end{abstract}

Keywords: Goat kids, parasitism, Haemonchus contortus, supplementation, urea-molasses blocks, mass gain, Kenya

\section{INTRODUCTION}

Gastrointestinal (GI) nematode parasitism dominated by haemonchosis, is one of the major constraints to profitable goat production in Kenya (Gatongi 1996; Githigia, Thamsborg, Munyua \& Maingi 2001). Goats develop little immunity against $\mathrm{Gl}$ helminths with age

\footnotetext{
* Author to whom correspondence is to be directed. E-mail: rmwaruiru@yahoo.co.uk
}

Accepted for publication 7 April 2004-Editor
(Hoste \& Chartier 1998) and they must be drenched several times a year to avoid high nematode burdens. The high frequency of anthelmintic treatment, without alternation between anthelmintic families is one of the reasons for the rise in anthelmintic resistance in goats in Kenya (Wanyangu, Bain, Rugutt, Nginyi \& Mugambi 1996; Waruiru, Kogi, Weda \& Ngotho 1998; Waruiru, Ngotho, Mutune \& Munyua 2003) Thus, the control of helminthosis in goats needs alternatives to chemicals. Several of these are based upon grazing management, such as the 
dose and move system, alternate grazing schemes with different ruminant species (Barger 1997), biological control (Larsen 1999) or improved nutrition (Coop \& Kyriazakis 1999).

In most parts of the country there are wide fluctuations in nutritional availability from pastures throughout the year and quality of this resource deteriorates due to seasonal influence and animal productivity declines unless supplements are offered. Productivity is likely to be even lower in animals suffering from Gl parasitism (Sykes 1994). Working in the rangelands of Kenya, Njanja (1991) observed that GI nematodes were the most important helminths in ruminants with clinical helminthosis occurring in the late dry season when the animals were also under nutritional stress. To increase productivity of small ruminants, alternative nutritional practices should be developed and these should include feed supplementation by use of multinutrient blocks containing fermentable nitrogen and other microbial growth factors which enhance digestibility of crop residues and straw by manipulation of rumen functions (Leng, Preston, Sansoucy \& Kunju 1991). The use of lowcost supplements such as urea molasses blocks (UMB) can enhance the animal's ability to utilize the available diet and assist the animal to withstand infection with resultant substantial increase in productivity. The aim of the present study was to determine the influence of UMB supplementation on productivity and GI nematode parasitism in naturally infected grazing weaner goats.

\section{MATERIALS AND METHODS}

\section{Study site}

The study was conducted between July 2001 and June 2002 on a farm at Turasha in Kipipiri Division of Nyandarua District, Kenya. The area lies at an altitude of $1200 \mathrm{~m}$ above sea level and is semi-arid. The annual rainfall varies between $750 \mathrm{~mm}$ and $1500 \mathrm{~mm}$ and falls between March and May (long rains) and again between August and November (short rains). January and March are usually the hottest months while July and August have the lowest mean monthly temperatures (Anon. 1997). The vegetation consisted of natural pasture which was dominated by Naivasha star grass (Cynodon plectostachyus) with scattered dwarf Acacia spp. The pasture was grazed each year by cattle, sheep and goats reared in a traditional husbandly system. The stocking rate was about nine animals per hectare. Daily records of rainfall, temperature and relative humidity were kept throughout the study period.

\section{Feed block manufacture}

The UMBs consisted of fertilizer grade urea ( $46 \%$ $\mathrm{N}$ ), cement (as binding material), sugarcane molasses, common salt, mineral premix $(\mathrm{NaCl}, \mathrm{Ca}, \mathrm{P}, \mathrm{Mg}$, $\mathrm{Fe}, \mathrm{Cu}, \mathrm{Mn}, \mathrm{Zn}, \mathrm{S}, \mathrm{Co}$, I, Se and Mo), maize germ (as bulking product) and water at proportions of $10 \%, 12 \%, 25 \%, 4 \%, 4 \%, 35 \%$ and $10 \%$, respectively. The UMBs were prepared by cold process using a concrete mixer (Sansoucy 1986; Bain 1999) as follows: initially, half the water (five parts) was thoroughly mixed with the urea until the urea granules dissolved. The cement and most of the remaining water (three parts) was added and mixed. Then, molasses, salt, mineral premix and the remaining water (two parts) were added to the mixture and mixed. Thereafter, maize germ was added in small quantities at a time and was mixed thoroughly until the mixture was even and without lumps. The mixture was poured into a mould (plastic basin, $5 \ell$ in capacity) and allowed to set for a day after which the block was taken out by inverting the basin over and knocking the bottom and sides. It was air-dried for 2 weeks before use (Bain 1999).

\section{Feed analysis}

Samples of pasture and UMB were taken monthly and each combined for laboratory analysis. Proximate analysis was done to determine the dry matter, ash, crude protein, crude fibre, ether extract, acid detergent fibre and neutral detergent fibre using the procedure outlined by McDonald, Edwards \& Greenhalgh (1988). The mineral (Ca, P, Mg, K, Na, $\mathrm{Fe}, \mathrm{Zn}, \mathrm{Cu}$ and $\mathrm{Mn}$ ) concentrations in the feeds were determined using standard procedures (MAFF/ADAS 1981).

\section{Study design}

In June 2001, 30 female Small East African goat kids and aged between 4 and 6 months were weighed, treated orally with albendazole $(A B Z)$ (Valbazen ${ }^{\circledR}$, Ultravetis East Africa Ltd., Nairobi, Kenya, $5 \mathrm{mg}$ $\mathrm{kg}^{-1}$ body mass), and maintained as a group. Based on their mass (the kids had a mean mass of $16 \mathrm{~kg}$; range $14-19 \mathrm{~kg}$ ), they were randomly allocated to one of two groups each consisting of 15 animals. The group I kids (UMB group) were fed UMBs for 3 consecutive months as follows: July to September 2001 (dry cold season) and for a further 3 months from January to March 2002 (dry hot season). This was preceded by an adaptation period of 2 weeks in June 2002 with the blocks for the group (McBeath, Preston \& Thompson 1979). All the blocks were weighed daily during the adaptation period 
and during the first 14 days of each supplementation period. Each block weighed $5 \mathrm{~kg}$ and it was calculated that 1.5 blocks were required to provide an average intake of $3.4 \mathrm{~g} \mathrm{~kg}^{-1}$ body mass, equivalent to about $100 \mathrm{~g} \mathrm{head}^{-1}$ day $^{-1}$ (Sansoucy 1986). Five blocks were put out initially and were replaced as they were consumed. The animals had unrestricted access to the blocks while they were housed each night. The group II (control group) kids received no block supplementation (NBS). All the kids grazed together for $8 \mathrm{~h}$ during the day but were housed separately at night when the UMBs were made available to the group I kids. Individual body mass was recorded for each animal before the study commenced and at monthly intervals thereafter.

Rectal faecal samples were collected at the commencement of the study and at monthly intervals thereafter. A modified McMaster technique was used to determine the number of nematode worm eggs per gram of faeces (Anon. 1986). Group bulked faeces were cultured and infective nematode larvae $\left(L_{3}\right)$ identified and expressed as the percentage of species recorded (Anon. 1986). Five goats from each group were randomly selected at the end of June 2002 and slaughtered for total and differential worm counts. The worms were recovered using standard methods (Anon. 1986).

\section{Statistical analysis}

The differences in live mass gains, faecal egg and worm counts (FEC; WC) between groups were analyzed by repeated measures analysis of variance, using the general linear model procedure on the SAS package (SAS Institute Inc. 1989-1996). Data for FEC and WC were transformed before analysis by taking $\log _{10}$ (count +50 ) to stabilize variance within groups. Geometric group means were calculated for these measurements.

\section{RESULTS}

\section{Meteorological data}

During the study period, rainfall distribution was generally bimodal with the short rains coming between September and November and the long rains between March and June (Fig. 1). The minimum temperature fluctuated between the range $7.1-20^{\circ} \mathrm{C}$ while the maximum temperature range was between $20^{\circ} \mathrm{C}$ and $30^{\circ} \mathrm{C}$. Relative humidity showed a peak (60-90\%) between April and August while the lowest (about $50 \%$ ) occurred between December and March.

\section{Faecal egg and worm counts}

The monthly geometric means of the FEC for the two groups are given in Fig. 1. The initial oral administration of $A B Z$ was effective in reducing the existing nematode infections, as evidenced by the reduction of FEC to zero in August. There was a gradual rise in FEC in August to December, during the short rains with no significant differences between FEC of UMB and NBS groups $(P>0.05)$. In both groups, the FEC gradually declined until February when it rose and was sustained until June. This coincided with the long rains. The UMB group had significantly $(P<0.05)$ lower FEC from January until the end of the observations (Fig. 1).

In the pooled faecal cultures from each group Haemonchus sp. (74\%), Trichostrongylus sp. (20\%) and Oesophagostomum sp. (6\%) were identified as the predominant larval types but there were no significant differences in the generic composition of the $\mathrm{L}_{3}$ from the UMB and NBS groups $(P>0.05)$.

There was a significant difference in the total WC between the UMB and NBS groups $(P<0.05)$. The mean $( \pm$ SD) for the UMB group was $482 \pm 299$ (range 108-1557) while that for the NBS group was $1302 \pm 410$ (range 211-3 768). Haemonchus contortus was the most prevalent GI nematode. Other nematodes recovered in decreasing order were Trichostrongylus colubriformis, Oesophagostomum columbianum, Nematodirus filicollis, Bunostomum trigonocephalum and Trichuris ovis.
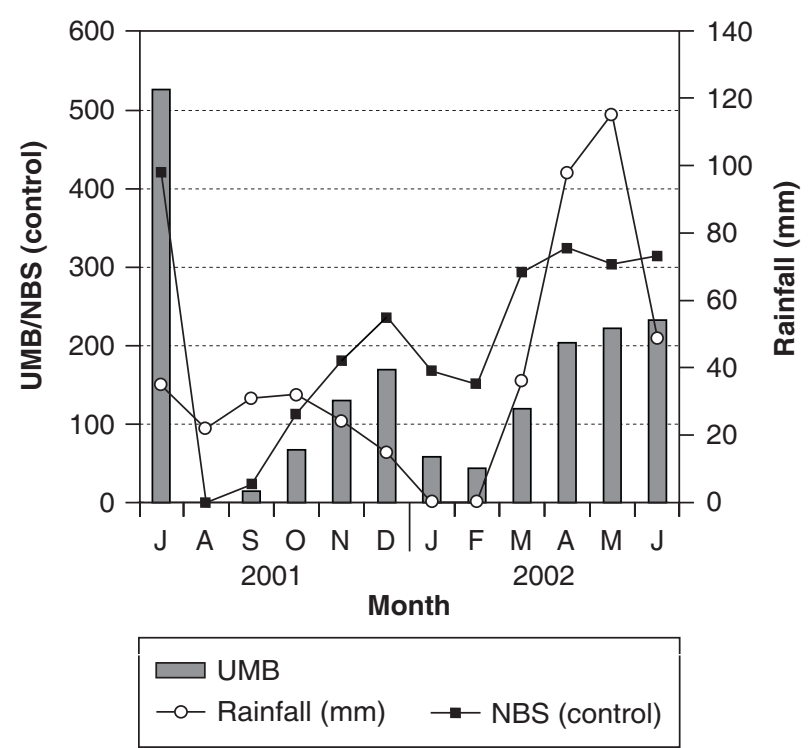

FIG. 1 Geometric mean strongyle eggs per gram of faeces for the UMB and NBS groups of goats during July 2001 to June 2002 and total monthly rainfall figures 
Urea-molasses block supplementation on grazing weaner goats

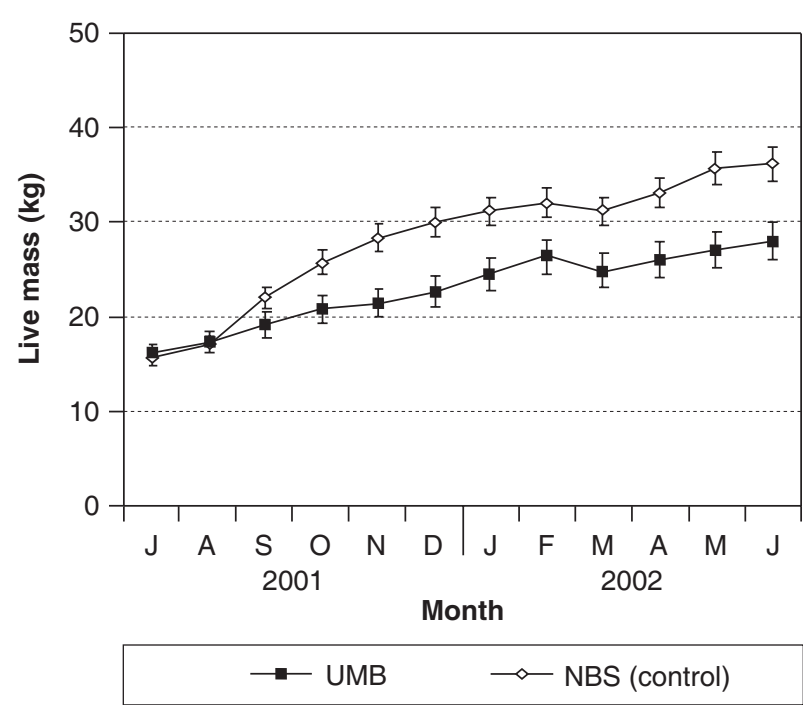

FIG. 2 Mean ( \pm SD) live mass of UMB and NBS groups of goats during July 2001 to June 2002
TABLE 1 Chemical and mineral composition of the dietary ureamolasses block (UMB) and pasture

\begin{tabular}{|c|c|c|}
\hline \multirow{2}{*}{ Chemical/mineral composition } & \multicolumn{2}{|l|}{ Feed } \\
\hline & UMB & Pasture \\
\hline Dry matter (\%) & 68.18 & 97.52 \\
\hline Ash (\%) & 36.48 & 7.51 \\
\hline Crude protein (\%) & 6.38 & 0.75 \\
\hline Ether extract (\%) & 3.43 & 2.00 \\
\hline Crude fibre $(\%)$ & 6.57 & 38.31 \\
\hline Neutral detergent fibre (\%) & 23.40 & 44.57 \\
\hline Acid detergent fibre (\%) & 10.65 & 40.01 \\
\hline In-vitro dry matter digestibility (\%) & 79.58 & 66.62 \\
\hline Calcium (\%) & 6.82 & 0.28 \\
\hline Phosphorus (\%) & 1.29 & 0.13 \\
\hline Magnesium (\%) & 1.31 & 0.21 \\
\hline Potassium (\%) & 1.80 & 0.90 \\
\hline Sodium (\%) & 3.96 & 0.06 \\
\hline Iron (\%) & 0.41 & 0.05 \\
\hline Zinc (ppm) & 314.00 & 24.00 \\
\hline Copper (ppm) & 120.00 & 1.00 \\
\hline Manganese (ppm) & 785.00 & 36.00 \\
\hline
\end{tabular}

\section{Feed analysis and urea-molasses block consumption}

The nutrient compositions of the UMB and pasture are shown in Table 1. The pasture was deficient in nitrogen with a crude protein $(\mathrm{CP})(\mathrm{N} \times 6.25)$ equivalent of $6.3 \%$. The mean daily block consumption for the UMB group during the adaptation period (June) was $92.6 \mathrm{~g}$. The average daily consumption of blocks by the same group during the two phases of supplementation was $95.1 \mathrm{~g}$ (July) and $97.3 \mathrm{~g}$ (January), respectively; an average consumption rate of $95.0 \mathrm{~g}, 95 \%$ of the $100 \mathrm{~g}$ intended. No adverse reactions associated with feeding the UMB were observed.

\section{Live mass gain}

The goats in the two groups had similar growth rates up to August 2001 (Fig. 2). Thereafter, the UMB group gained significantly more mass than the NBS group $(P<0.05)$. Overall, the goats in the UMB group gained an average ( \pm SD) of $20.4 \pm 1.4 \mathrm{~kg}$ $\left(153.1 \pm 39.8 \mathrm{~g} \mathrm{day}^{-1}\right)$, while the NBS group gained an average of $11.8 \pm 1.1 \mathrm{~kg}\left(83.8 \pm 22.1 \mathrm{~g} \mathrm{day}^{-1}\right)$ during the study period.

\section{DISCUSSION}

The FEC profiles of the UMB and NBS groups showed a seasonal pattern which was related to the rainfall distribution. During the rains, the environmental conditions were ideal for the development and transmission of $L_{3}$ on the pasture. This was emphasized in both groups when worm egg output reached their peaks in December (short rains) and April (long rains). The FEC indicated low to moderate worm burdens, consistent with subclinical parasitism throughout the study period. The results of differential larval and WC indicated that $H$. contortus was the predominant nematode species. Other nematodes identified included $T$. colubriformis, $N$. filicollis, B. trigonocephalum, O. columbianum and $T$. ovis, and these observations agree with earlier studies on goats in marginal areas of central Kenya (Waruiru, Gichanga, Kimoro \& Karanu 1994; Gatongi 1996; Githigia et al. 2001).

The FEC (from January) and WC of the UMB group were significantly different from those of the NBS group. These findings are in agreement with reported data showing that urea supplementation generally resulted in lower FEC of sheep with mixed nematode infections in both pen and field situations (Knox \& Steel 1996). There was no significant difference in the species composition of worms between the groups, indicating that UMB supplementation had no effect on the distribution of GI nematode species in the goats.

The pasture was deficient in $\mathrm{N}$ and this may have limited rumen microbial activity (Van Soest 1982). On average, the goats consumed $95.0 \mathrm{~g}$ of $\mathrm{UMB}^{-1}$ 
day $^{-1}$ and the CP contribution from this enhanced the growth rate of the goats given the fact that the basal diet was $\mathrm{N}$-deficient. No cases of urea toxicity were recorded during the study. The UMB were offered in a block form with the intention that the animals should lick them rather than in chopped form which may have led to the consumption of toxic doses of urea (Tibbo, Amare, Haile \& MukasaMugerwa 1998).

The UMB group had greater mass gains than the NBS group. Knox \& Steel (1996) showed that such blocks had a positive effect on the growth of sheep fed a low quality roughage diet and reduced the level of infection and debilitating effects of GI nematode infections. This response is partly due to the stimulatory effect of the urea on feed intake counteracting the depressive effect of the parasites on appetite (Kyriazakis, Tolkamp \& Hutchings 1998).

In conclusion, the UMBs assisted the goats to overcome the detrimental effects of GI nematode parasitism which confirms previous observations that well fed animals are better able to overcome the effects of helminth infections (Knox \& Steel 1996; Waruiru, Onyando \& Machuka 2003). The use of UMBs should be considered as an integral part of animal husbandry practice on Kenyan farms as well as elsewhere in sub-Saharan Africa (Rajkomar 1988).

\section{ACKNOWLEDGEMENTS}

The present investigation was made possible by financial support from the Livestock Helminth Research Project within the Danish International Development Agency (DANIDA) ENRECA programme.

\section{REFERENCES}

ANON. 1986. Manual for parasitological techniques, Ministry of Agriculture, Fisheries and Food. London: HMSO (Technical Bulletin, no. 18).

ANON. 1997. Nyandarua District development plan (1997-2001), Rural Planning Department, Office of the Vice President and Ministry of Planning and National Development.

BAIN, R.K. 1999. Integrated Helminth Control. Kenya Agricultural Research Institute/Department for International Development, National Agricultural Research Project II (KARI Technical Note, no. 2).

BARGER, I.A. 1997. Control by management. Veterinary Parasitology, 72:493-506.

COOP, R.L. \& KYRIAZAKIS, I. 1999. Nutrition-parasite interaction. Veterinary Parasitology, 84:187-204.

GATONGI, P.M. 1996. Epidemiology and control of haemonchosis of small ruminants in semi-arid Kenya. Kenya Agricultural Research Institute Information, April 1996 (Bulletin no. 17).
GITHIGIA, S.M., THAMSBORG, S.M., MUNYUA, W.K. \& MAINGI, N. 2001. Impact of gastrointestinal helminths on production in goats in Kenya. Small Ruminant Research, 42:21-29.

HOSTE, H. \& CHARTIER, C. 1998. Resistance des chevres aux strongyloses gastrointestinales: differences avec les moutons. Point Veterinaire, 29:69-74.

KNOX, M. \& STEEL, J. 1996. Nutritional enhancement of parasite control in small ruminant production systems in developing countries of south-east Asia and the Pacific. International Journal for Parasitology, 26:963-970.

KYRIAZAKIS, I., TOLKAMP, B.J. \& HUTCHINGS, M.R. 1998. Towards a functional explanation for the occurrence of anorexia during parasitic infections. Animal Behaviour, 56:265274.

LARSEN, M. 1999. Biological control of helminths. International Journal for Parasitology, 72:493-506.

LENG, R.A., PRESTON, T.R., SANSOUCY, R. \& KUNJU, P.J.G. 1991. Multinutrient blocks as a strategic supplement for ruminants. World Animal Review, 67:11-19.

MAFF/ADAS 1981. The Analysis of Agricultural Materials, $2^{\text {nd }}$ ed., RB427, London: HMSO.

MCBEATH, D.G., PRESTON, N.K. \& THOMPSON, F. 1979. Studies on the efficacy of fenbendazole administered via feed-block carrier. British Veterinary Journal, 135:271-278.

MCDONALD, P., EDWARDS, R.A. \& GREENHALGL, J.F.D. 1988. Animal Nutrition, $4^{\text {th }}$ ed., Essex: Longman Scientific and Technical.

NJANJA, J.C. 1991. Livestock ecology in central Turkana. TREMU Technical Report E-1, Unesco, Nairobi, Kenya.

RAJKOMAR, B. 1991. The molasses block technology in Mauritius and the African perspective. Livestock Research in Rural Development, 3:52-62.

SANSOUCY, R. 1986. The Sahel: manufacture of molassesurea blocks. World Animal Review, 57:40-48.

SYKES, A.R. 1994. Parasitism and production in farm animals. Animal Production, 59:155-172.

TIBBO, M., AMARE, H., HAILE, A. \& MUKASA-MUGERWA, E. 1998. Urea-toxicity associated with urea-molasses block feeding in lambs in the central highlands of Ethiopia. Bulletin of Animal Health and Production in Africa, 46:175-180.

VAN SOEST, P.J. 1982. Nutritional Ecology of the Ruminant, Oregon, USA: O \& B Books Inc.

WANYANGU, S.W., BAIN, R.K., RUGUTT, M.K., NGINYI, J.M. \& MUGAMBI, J.M. 1996. Anthelmintic resistance amongst sheep and goats in Kenya. Preventive Veterinary Medicine, 68:183-189.

WARUIRU, R.M., GICHANGA, E.J., KIMORO, C.O. \& KARANU, F.N. 1994. The prevalence of gastrointestinal nematodes, coccidia and lungworms in Ol'Magogo dairy goats. Bulletin of Animal Health and Production in Africa. 42:291-295.

WARUIRU, R.M., KOGI, J.K., WEDA, E.H. \& NGOTHO, J.W. 1998. Multiple anthelmintic resistance on a goat farm in Kenya. Veterinary Parasitology, 75:191-197.

WARUIRU, R.M., NGOTHO, J.W., MUTUNE, M.N. \& MUNYUA, W.K. 2003. Comparative efficacy of ivermectin, albendazole, levamisole and rafoxanide against gastrointestinal nematode infections in goats. Indian Journal of Animal Sciences, 73:147-150.

WARUIRU, R.M., ONYANDO, C.O. \& MACHUKA, R.O. 2003. Effect of feeding urea-molasses blocks with incorporated fenbendazole on grazing dairy heifers naturally infected with gastrointestinal nematodes. Journal of the South African Veterinary Association, 74:49-52. 